\title{
The unknown face of labial salivary glands. Labial salivary gland biopsy as a diagnostic tool
}

\section{Nieznane oblicze wargowych gruczołów ślinowych. Biopsja wargowych gruczołów ślinowych jako narzędzie diagnostyczne}

\author{
Bartłomiej Kamiński', Zbigniew Guzera² \\ ${ }^{1}$ Otolaryngology Ward, Maria Sklodowska-Curie District Hospital, Skarżysko-Kamienna, Poland \\ Head of the Ward: Bartłomiej Kamiński MD, PhD \\ ${ }^{2}$ Holy Cross Center of Rheumatology, St. Luke Hospital, Końskie, Poland \\ Head of the Department: Zbigniew Guzera MD
}

Key words: sarcoidosis, amyloidosis, Sjögren's syndrome, salivary glands, labial salivary gland biopsy.

Słowa kluczowe: sarkoidoza, amyloidoza, zespół Sjögrena, gruczoły ślinowe, biopsja wargowych gruczołów ślinowych.

\begin{abstract}
Labial salivary gland biopsy (LSGB) is a minimally invasive and safe surgical procedure performed in the diagnosis and monitoring of selected diseases such as Sjögren's syndrome (SS), sarcoidosis, and amyloidosis. The aim of this study is to present the main possibilities and indications for the usefulness of LSGB in these diseases, their histopathological criteria, and the main advantages and limitations. Histopathological confirmation of SS is based on the presence of lymphocytic infiltrates, known as focal lymphocytic sialadenitis (FLS). FLS refers to the histopathological pattern of the presence of one or more foci in the biopsies, while the tissue surrounding the foci is composed mainly of unaffected parenchyma. A focus is defined as an aggregate of $\geq 50$ lymphocytes, and the focus score (FS) is the total number of foci per $4 \mathrm{~mm}^{2}$ of salivary gland tissue. FLS should be distinguished from other types of sialadenitis such as nonspecific chronic sialadenitis, sclerosing chronic sialadenitis, granulomatous inflammation, and lymphomas.
\end{abstract}

\section{Streszczenie}

Biopsja wargowych gruczołów ślinowych (LSGB) jest minimalnie inwazyjnym i bezpiecznym zabiegiem chirurgicznym wykorzystywanym w diagnostyce i monitorowaniu wybranych chorób, takich jak zespół Sjögrena (SS), sarkoidoza, amyloidoza. Celem pracy było przedstawienie głównych możliwości i wskazań do zastosowania LSGB, kryteriów histopatologicznych, głównych zalet i ograniczeń. Histopatologiczne potwierdzenie SS opiera się na stwierdzeniu obecności nacieków limfocytarnych znanych jako ogniskowe limfocytarne zapalenie gruczołów ślinowych (FLS). Nazwa FLS odnosi się histopatologicznie do obecności jednego lub więcej ognisk w biopsji, podczas gdy ognisko jest otoczone głównie przez niezmienioną tkankę miąższową. Ognisko jest definiowane jako skupisko 50 lub więcej limfocytów, a wynik jest liczbą ognisk przypadającą na $4 \mathrm{~mm}^{2}$ tkanki gruczołowej. Ogniskowe limfocytarne zapalenie gruczołów ślinowych powinno być różnicowane z innymi typami zapalenia, takimi jak niespecyficzne zapalenie gruczołów ślinowych, twardniejące przewlekłe zapalenie gruczołów ślinowych, zapalenie ziarniniakowe i chłoniaki.

\section{Introduction}

Labial salivary gland biopsy (LSGB) is a minimally invasive and safe surgical procedure performed when diagnosing and monitoring selected diseases. Histopathological changes in labial salivary glands are representative for these pathologies, and LSGB is characterised by high disease specificity, sensitivity, and predictive value. Labial salivary glands represent small (1-5 mm), scattered, lobular structures, which lie superficially in the mucosal area of the lips. They consist of mixed (serous and mucous) or only mucous acini and a ductal excretory system that is histologically different from that of the major salivary glands because of the absence of striated-type ducts within the labial salivary glands [1]. The labial salivary glands, which are readily accessible compared with other salivary glands, may be biopsied through normal-appearing mucosa in the endobuccal border of the lower lip after local anaesthesia [2]. Labial salivary gland biopsy is a simple surgical procedure and may be carried out on an ambulatory basis. There are many surgical approaches in taking labial salivary 
glands. Their aim is to obtain sufficient glandular tissue and to reduce the possible postoperative complications. The most commonly reported complications of LSGB are hypoesthesia or numbness of the lower lip, haematoma, local swelling and pain, burning or tingling, failing sutures, internal scarring and keloid formation, and the formation of granulomatous tissue [3]. Immediate post-biopsy-period functional deficits includes a mild degree of difficulty with eating, speech, and sleep [4]. The permanent sensory loss of the mucosa of the lower lip is assessed from $1 \%$ to $10 \%$, according to the surgical technique [3].

The aim of this study is to present the main indications for LSGB in selected diseases, their histopathological criteria, and the main advantages and limitations.

\section{Labial salivary gland biopsy in diagnosing and monitoring Sjögren's syndrome}

Sjögren's syndrome (SS) is an autoimmune disease characterised by chronic T-and B-cell infiltration of the salivary and lachrymal glands, leading to exocrine gland dysfunction with symptoms of dry mouth and keratoconjunctivitis sicca. If lacrimal glands are affected, it is called Mikulicz disease. However, the clinical presentation of SS covers a broad spectrum with variable combinations of systemic extra-glandular manifestations such as peripheral neuropathy, arthralgia, lung disease, skin and mucosa manifestations, and other features [5-11]. The population prevalence of SS has been estimated at $0.5-1 \%$, and the male/female ratio is approximately $1: 9$. Sjögren's syndrome can occur as a primary disease (pSS) or in association with another connective tissue disease as a secondary SS (sSS) [5-11]. The presence of mononuclear cell aggregates around the ducts and acini of exocrine glands result in functional and structural alternations at the level of these glands and impair their secretory function [4]. As well as the direct relationship between mononuclear cell infiltrations and secretory function, there are alternative pathways, such as induction of apoptosis of epithelial glands, alternations in aquaporin distribution, or inhibition of neurotransmission by antimuscarinic antibodies, which lead to impaired glandular homeostasis [5]. Some of these molecular changes are reflected in histopathological examinations of labial salivary glands. Biopsy of the labial minor salivary glands is considered a diagnostic technique with high specificity for SS, with few postsurgical complications. Moreover, LSGB is an objective diagnostic test of SS. Nevertheless, its regular use for SS diagnosis is not routine, especially due to the need for careful histological evaluation of the specimens and the invasive nature of the procedure [10]. Previous classifications of SS were based on the combination of both objective and subjective tests. They included clinical, serological, and histopatho- logical features of SS [7-10]. The current diagnostic criteria of SS, approved in 2016 by the American College of Rheumatology (ACR) and the European League Against Rheumatism (EULAR), are based on the sum of five items: anti-SSA/Ro antibody positivity and focal lymphocytic sialadenitis (FLS) with a focus score of $1 \mathrm{foci} / 4 \mathrm{~mm}^{2}$, each scoring 3; an abnormal ocular staining score of 5 (or a van Bijsterveld score of 4); a Schirmer's test result of $5 \mathrm{~mm} / 5 \mathrm{~min}$; and an unstimulated salivary flow rate of $0.1 \mathrm{ml} / \mathrm{minute}$, each scoring 1 . Individuals with signs and/or symptoms suggestive of SS, who have a total score of 4 for the above items, meet the criteria for primary SS [12-14]. In current classification, the presence of either anti-SSA/SSB seropositivity or a positive lip biopsy is a requirement for an individual to be classified as having SS [4]. The histopathological diagnosis of SS is based on the presence of lymphocytic infiltrates, known as focal lymphocytic sialadenitis (FLS), located around the striated ducts. The foci are mainly composed of T- and B-lymphocytes with a few other mononuclear cells, including macrophages, myeloid and plasmacytoid dendritic cells, and follicular dendritic cells. They may develop into organised lymphoid tissue resembling secondary lymphoid organs with segregated Tand B-cell areas, and high endothelial venules. The term FLS refers to the histopathological pattern of the presence of one or more foci in the biopsies, while the tissue surrounding the foci is composed mainly of unaffected parenchyma. A focus is defined as an aggregate of $\geq 50$ lymphocytes, and the focus score (FS) is the total number of foci per $4 \mathrm{~mm}^{2}$ of salivary gland tissue. In the labial glands a FS $>1$ is considered as a positive biopsy and used for the classification of pSS [15]. Specimens can exhibit other patterns of chronic inflammation, which are classified as nonspecific chronic sialadenitis (NSCS) or sclerosing chronic sialadenitis (SCS) depending on the presence of interstitial fibrosis, atrophic or absent acini, and scattered or focal chronic inflammation. All histopathological patterns with diffuse lymphocytic infiltrations exclude the confirmation of SS. Fibrosis and atrophy of acini can occur in other types of sialadenitis and cannot be treated as SS-specific features. These aggregates are not counted in the focus score because of the absence of adjacent normal acini. Specimens containing epithelioid histiocytes and occasional Langerhans-like multinucleated giant cells forming noncaseating granulomas are further examined by immunohistochemistry to detect the CD68 expression. In such cases, the absence of acid-fast bacilli in the specimen would lead to recommending that the participant be evaluated for sarcoidosis or other chronic granulomatous disease. Some specimens with no apparent lymphocytic infiltration or other inflammation are classified as "within normal limits". Focal lymphocytic sialadenitis should be distinguished from other types 
of sialadenitis, which are characterised by mild to moderate acinar atrophy, intestinal fibrosis, and ductal dilatation. In NSCS lymphocytes and macrophages are scattered in the parenchyma but do not form dense aggregates of 50 or more lymphocytes immediately adjacent to normal-appearing acini [4]. Nonspecific chronic sialadenitis is present when there are scattered or focal infiltrates of lymphocytes, macrophages, and plasma cells that are not adjacent to normal-appearing acini and are located in gland lobules that exhibit a combination of acinar atrophy, interstitial fibrosis, duct dilation, and luminal inspissated mucus [16]. Sclerosing chronic sialadenitis appears to be an advanced stage of NSCS in which interstitial fibrosis, various patterns of chronic inflammation, and acinar atrophy predominate [16]. In addition to sialadenitis, several other disturbances of the labial glands can be diagnosed. Granulomatous inflammation, florid lymphoid hyperplasia with germinal centres as well as marginal zone (MALT) lymphoma are observed. Normal limits are diagnosed in the minor salivary glands with normal-appearing architecture and scattered plasma cells, but without acinar atrophy and few, if any, lymphocytes. Granulomatous inflammation is present when there are clusters of CD68positive macrophages, with or without occasional multinucleated giant cells and absent necrosis. Germinal centre presence is estimated in H\&E stained sections by the presence of a cluster of relatively clear staining cells within a lymphocytic focus. More specific identification of germinal centres requires immunohistochemical staining for follicular dendritic cells with anti-CD21 or CD23 [16]. The median FS is higher in specimens with evidence of germinal centre formation compared with those without and showing a strong association between higher focus scores and the presence of germinal centres. The presence of FLS is highly associated with both the serological and ocular components of SS and is significantly more specific for the salivary component of SS than unstimulated salivary flow rate $<0.1 \mathrm{ml} / \mathrm{min}$. The LSGB is generally a minimally invasive procedure that can yield histopathological information about the extent and nature of the disease process. The greatest weakness of LSGB is inconsistent histopathological assessment [16]. The sensitivity of labial gland biopsy in SS diagnosis ranges from $63.5 \%$ to $93.7 \%$ and specificity from $61.2 \%$ to $100 \%$ [17]. According to other studies, the sensitivity of LSGB ranges from $60 \%$ to $82 \%$ and specificity ranges from $91 \%$ to $94 \%$ [3]. The LSGB can also be applied in diagnosing childhood SS and there is a need to set a child-specific positive focus score [18]. Not all pSS patients have a positive salivary gland biopsy. In 18 $40 \%$ of pSS patients, the labial gland biopsy is negative, especially in FS $<1$. These patients are at risk of being misclassified as non-pSS according to the ACREULAR criteria. Moreover, foci can also be found in healthy individuals: $6-9 \%$ of healthy individuals have a FS of $>1.0$ in labial gland biopsy. Limitations in FSL assessment are age differences in labial glands. Specimens from older patients exhibit periductal sclerosis. The presence of sclerosis is consistent with an earlier observation that there is a proportional increase in salivary gland fibrous tissue with increasing age [16]. The grading scheme for assessing inflammation in LSGB applies to both qualitative and semiquantitative assessments of lymphocytic infiltration to the labial salivary glands. Some pathologists do not perform the semi-quantitative part of assessing LSGB to develop a focus score or do it incorrectly. The LSGB must first be diagnosed qualitatively to assess the presence of FLS vs. NS/SCS: if FLS is present, then focus score assessment should follow, but if NS/SCS is present, a focus score is unnecessary and would be misleading if performed [16]. The LSGB should not be repeated, and it is not recommended for evaluating treatment and disease activity. The FS is based on the number of foci, and there is a possible miscalculation in the diagnostic process. The next limitation of LSGB arises from sufficient glandular specimens. It may be difficult to obtain a diagnostic amount of glandular tissue in atrophic mucosa, especially in patients with longstanding SS. Inadequate sampling can lead to misdiagnosis or lack of diagnosis. There has been a lack of standardisation in biopsy techniques. The surgical technique should provide pure glandular specimens with a sufficient number of labial glands and without other tissue compartments, such as muscular or fibrous tissues. Although the presence of other tissues has no impact on final diagnosis, inadequate specimens with other tissues can disturb the diagnostic process. The most important is specimen size, lack of tissue crush, well-preserved glandular tissue, and good clinician-pathologist communication. The tissue specimens should include four labial salivary glands without other tissue compartments. Immunosuppressive drugs and steroids can also confuse histopathological results. Oral steroids and immunosuppressive drugs at the time of biopsy are factors potentially contributing to false-negative results of LSGB $[4,19]$. Problems in assessing the FS also arise when other histopathological patterns, such as nonspecific chronic sialadenitis or sclerosing chronic sialadenitis, are present. Furthermore, features such as acinar atrophy, intestinal fibrosis, and an increase in fat cells are frequently present in the biopsy. These features are associated with age in healthy individuals. There is no consensus on whether there is an increase in the amount of adipose tissue in labial gland biopsies of SS patients compared to age-matched healthy controls. It is probably the case that an increased area of adipose tissue in the labial gland biopsy is not specifically associated with SS but is a selective feature of aging. An important drawback of the 
FS is that it is only based on the number of foci and does not include the size of these foci. The area of infiltrate can be evaluated. This gives a more precise indication of how much glandular tissue is involved in the inflammation [15].

In addition to periductal infiltrates, there are also other histopathological features in the glands that are associated with SS and therefore might be indicative for this disease. Besides FLS, lymphoepithelial lesions (LELs) and a relative decrease in IgA plasma cells appear to be characteristic for SS. Both features can help assess the salivary gland biopsies for the diagnosis of SS, especially when the FLS in the biopsy is $<1$. Lymphoepithelial lesions are striated ducts that are infiltrated by lymphocytes with concurrent hyperplasia of the epithelial cells. These infiltrated lymphocytes cause the hyperplasia of the epithelium and occlusion of the striated ducts. Lymphoepithelial lesions and lymphoid follicle formation can be assessed using immunohistochemistry with immunomarker CD3. The same immunomarker is helpful in the detection of focal or partial villous atrophy in patients suspected of celiac disease in small intestinal mucosal biopsies. The percentage of CD3-positive intraepithelial lymphocytes corresponds to the severity of villous atrophy and other histological features of celiac disease as crypt hyperplasia, plasma cell number, eosinophil number, and neutrophil presence. Moreover, other immunomarkers such as CD4 and CD8 play a similar diagnostic role. LELs in SS can be found both in labial and in parotid glands, but they seem to be more pronounced within the parotid gland tissue. They are considered histopathological criteria of SS in parotid gland biopsy. These structures are always associated with periductal infiltrates, and solitary LELs are not present. In pSS patients LELs are present in 93\% of the parotid gland biopsy compared to $33 \%$ of the labial gland biopsies. Lymphoepithelial lesions detection in the labial salivary glands has limited value in SS diagnosis. Furthermore, LELs are not specific to SS, because HIV infections could also lead to cystic LELs within the glandular tissue. LELs comprise both B- and T-cells, and with the progression of the disease, relative number of B-cells within the lesions increases. The increasing number of B-cells in LELs can be an important factor of SS progression and severity. Besides LELs, the salivary glands of SS patients also show a relative decrease in IgA plasma cells. This parameter has a strong diagnostic value. A decrease of $<70 \%$ IgA in the labial biopsies of SS patients has a specificity of $95.4 \%$ and a sensitivity of $100 \%$. This decrease is more sensitive and more disease-specific than the FS. The combination of FS and $<70 \% \operatorname{IgA}$ can increase the indicative accuracy of the biopsies [15]. The main limitations of LSGB in the diagnosis of SS stem from the lack of standardisation of the surgical technique of the biopsy. The distribution of the inflammatory cells in the labial glands may be focal or diffuse. Considering this patchy distribution, a single tissue section may result in underdiagnosis. Multiple tissue sections at different tissue depths within the labial salivary gland may improve the accuracy of SS diagnosis by detecting specific features that may not have been detected in a single section [19].

\section{Detection of lymphomas accompanying Sjögren's syndrome}

Patients affected with SS have a higher risk of developing non-Hodgkin lymphoma (NHL) than the general population; this risk is estimated to be 44-times greater. This is the most serious complications of SS. The incidence of lymphomas in SS varies between $5 \%$ and $10 \%$. In most cases, they are extranodal B-cell lymphomas of low-grade and mucosaassociated lymphoid tissue (MALT) lymphoma, also known as extranodal marginal zone B-cell lymphoma. Marginal zone (MALT) lymphoma is diagnosed in minor salivary glands exhibiting diffuse lymphocytic infiltration with a loss of glandular architecture and composed of sheets of CD20-positive cells, a few scattered CD3-positive cells, and few, if any, follicular dendritic (CD21- or CD23-positive) cells [16]. Between $4 \%$ and $7 \%$ of patients with SS develop B cell lymphoma, $48 \%$ to $75 \%$ of which are of the MALT type. In SS, MALT lymphoma originates mainly in the major salivary glands, particularly from the parotid. Reported cases in the minor salivary glands are very rare $[13,14$, 20-24]. Parotid gland biopsy is recommended more for detection of MALT lymphomas accompanying SS than for labial biopsy. On the other hand, microscopic examinations of labial glands even in the initial stages of SS provide valuable signs of future lymphoma development. Despite considerable efforts to identify risk factors or biomarkers for the development of NHL, neither the patients who will develop NHL nor the expected time of the onset of lymphoma can be identified effectively. Some predictors have been repeatedly documented from large patient cohorts, namely hypocomplementaemia, persistent or recurrent salivary gland swelling, and cutaneous vasculitis or even palpable purpura tumour mass. The lymphoid organ in the form of germinal centre (GC)-like lesions was evaluated in labial salivary gland biopsies taken at SS diagnosis, and it was postulated as a potential lymphoma-predicting biomarker [15, 20-23]. GC-like structures are a sign of lymphoid tissue formation and organisation. In the majority of salivary gland biopsy samples, $\mathrm{T}$ and $\mathrm{B}$ cells are found in foci, and in $10-25 \%$ of salivary gland biopsy samples, germinal centres (GCs) are present [20]. A biopsy is considered GC positive $(\mathrm{GC}+)$ in cases in which a well-circumscribed chronic inflammatory cell infiltrate consisting of at least 50 mononuclear cells presents with features indicative of lymphoid organisation, such as 
a densely packed dark zone and a light zone within an otherwise normal salivary gland epithelium [15]. GC positivity corresponds with selected risk factors of lymphoma development and clinical variables such as lymphadenopathy, leucopaenia, hypergammaglobulinaemia, and organ involvement. Detection of GC-like lesions may allow the clinician to identify the target population for repeated NHL screening and possibly the selection of candidates for preventive Bcell-directed biological treatment in SS, by utilising a simple routine diagnostic procedure [15]. Furthermore, the vast majority of the B-cells within the LELs of SS patients express FcRL4. Fewer FcRL4 ${ }^{+}$B-cells are located outside the LELs but within the foci. The $\mathrm{FcRL}^{+} \mathrm{B}$-cells represent a small subset of highly proliferative mucosal memory B-cells. In salivary glands 93\%-97\% of MALT express FcRL4 ${ }^{+}[15,21]$.

\section{Labial salivary gland biopsy in amyloidosis}

Amyloidosis is a term used to describe a group of disorders that share a common feature, namely the extra-cellular deposition of the insoluble fibrillary protein amyloid in diverse organs and tissues. The current classification of amyloidosis is based on the nature of the plasma protein precursor that acts as the source of the fibril deposits. These plasma proteins are diverse in nature and unrelated, but all may produce amyloid deposits with a common beta-fibrillar structure. According to the predominant type of amyloid protein, there are two main forms of acquired systemic amyloidosis: AA or reactive (secondary) amyloidosis and $\mathrm{AL}$ (primary) amyloidosis. The diagnosis of AA is based on a clinical suspicion, and it is confirmed by a biopsy. The usual histological methods for demonstrating amyloid in biopsy specimens are limited by the fact that only a few anatomic sites can be submitted to this procedure, due to the obvious problem of sampling within organs with this invasive method. Biopsies of the kidney, liver, and spleen provide a high frequency of positive results, but they are risky and may result in severe complications. Labial salivary gland biopsy has been proven to be a safe, highly sensitive, and reliable method for diagnosis of secondary AA [25]. Although oral localisation of amyloidosis is well known and macroglossia is known to be one of the most common clinical manifestations, it is surprising that LSGB is rarely performed in the diagnosis of amyloidosis [26]. Labial salivary gland biopsy is characterised by the high sensitivity in the diagnosis of amyloidosis, even in the absence of oral symptoms [26]. The LSG biopsy materials from patients known to have systemic amyloidosis demonstrate a sensitivity of $86 \%$ and a specificity of $100 \%$ [26]. According to Suzuki et al., LSGB may be appropriate as a first-choice procedure to diagnose AL amyloidosis. The sensitivity for detecting amyloid deposition is highest in biopsies of labial salivary glands at $89 \%$, followed by $77 \%$ for bone marrow, and $72 \%$ for skin. Multiple biopsies of superficial tissues, including LSG, bone marrow, and skin, are recommended to increase the sensitivity for diagnosing AL amyloidosis [27]. The histopathological diagnosing of amyloidosis in labial salivary glands can be based on positive Congo red staining and confirmation under polarised light, anti-SAP antibody staining, and electron microscopy techniques $[26,28]$. Anti-SAP antibodies react with virtually all amyloid types and are useful to detect amyloid. Immunologic methods for diagnosing amyloid deposits are quite useful for identifying false-positive cases because tissues may stain positive for Congo red or the metachromatic stains in the absence of amyloid deposits. The use of antisera does not provide greater sensitivity, but it is quite helpful for pathological confirmation, particularly in cases with few deposits. Electron microscopy has been used to validate the method, but it is not appropriate for day-to-day practice. In patients with a family history of amyloidosis, studies of the genome and amyloid protein can identify the protein variants capable of causing systemic amyloidosis [29]. Amyloid deposits in LSG tissues are typically periductal and sometimes appear as isolated deposits [26].

\section{Labial salivary gland biopsy in sarcoidosis}

Sarcoidosis is a systemic disease of unknown cause, characterised by the formation of noncaseous granuloma, which most often involve the lung and the lymphatic system. Sarcoidosis may encompass numerous different clinical presentations. Typical presentations often prompt a rapid diagnosis, while in $25 \%$ to $50 \%$ of cases, diverse and less typical presentations may lead to delayed diagnosis. Mediastinopulmonary sarcoidosis covers from $85 \%$ to $95 \%$ of cases, associated with extrapulmonary localisations in half of cases, while extrapulmonary localisations without lung involvement may be seen in 5\% to $15 \%$ of cases. There is no single test for sarcoidosis, and the presence of granulomas alone does not establish the diagnosis. Symptoms of sarcoidosis are not specific and can be markedly different according to organ involvement and disease course. Respiratory symptoms and fatigue are the most common symptoms at any stage of disease. Sarcoidosis may also affect the orofacial region, and this manifestation belongs to orofacial granulomatosis. Oral lesions may also be evident in some patients and may represent the first clinical evidence of disease. Oral sarcoidosis typically manifests as non-specific painless ulcerations and/or nodules, and any mucosal site may be affected. Sarcoidosis of the gingiva may present as a generalised enlargement. Salivary gland involvement may also be evident in sarcoidosis patients. The parotid gland is affected the most frequent; submandibular and sublingual gland involvement are much 
less common. When the major glands are affected, the patients may present with either unilateral or bilateral enlargement. A clinical variant of sarcoidosis, known as Heerfordt syndrome (uveoparotid fever), is characterised by parotid gland enlargement, fever, uveitis, and facial palsy. The minor salivary glands within the lips and oral cavity may also be affected. A LSGB may be useful in the diagnosis of generalised sarcoidosis, even if there is no clinical evidence of oral or perioral involvement. All sarcoid granulomas in major and minor salivary glands have the same features; they are representative and common, and LSGB can confirm their presence. The diagnosis of sarcoidosis is based on a compatible clinical-radiological picture and the histological evidence of noncaseating granulomas. Other diseases mimicking sarcoidosis, mostly infections and other granulomatoses, have to be excluded. The radiological staging system is still based on chest radiography, and computed tomography is not mandatory for routine follow-up [30]. F-fluorodeoxyglucose positron emission tomography may be of value in special cases. For assessment of lung involvement and follow-up, pulmonary function tests are necessary, with vital capacity being the most important single parameter and diffusion capacity the most sensitive. Bronchoscopy with biopsy is the most common procedure for detection of granulomas, when there is no easier biopsy site like skin or peripheral lymph nodes. Endobronchial ultrasonography-guided transbronchial needle aspiration has replaced mediastinoscopy for the evaluation of mediastinal and hilar lymph nodes with a high diagnostic yield. Despite numerous studies, no single biomarker can be reliably used for correct diagnosis or exclusion of sarcoidosis. Genetic testing, despite promising advances, has still not been included in routine care for sarcoidosis patients [31, 32]. Labial salivary gland biopsy can be helpful in diagnosing sarcoidosis, especially in oral manifestations of disease. Its impact depends on involvement of the organ and clinical manifestation of sarcoidosis. Currently, LSGB is not a routine management in diagnostic process and is rarely performed. Labial salivary gland biopsy can be applied for the detection or confirmation of sarcoidosis or uveitis. This diagnosis is based on the presence of the sarcoid granulomas on the LSGB. Most studies reported that LSGB can be an additional test in the diagnosis of sarcoidosis and uveitis, and it should be performed together with ophthalmological features and the results of other relevant examinations, such as the serum levels of angiotensin converting enzyme (ACE) and a chest radiograph or CT scan. According to Bernard et al., the LSGB sensitivity $(18.75 \%)$ in patients with proven sarcoidosis appears to be too low, and it is a possible method of tissue diagnosis in patients with raised ACE and/or a CT scan pattern compatible with sarcoidosis, and it should not be performed in patients with unexplained uveitis or because of their ophthalmological features [33].

\section{Labial salivary gland biopsy in neonatal haemochromatosis}

Neonatal haemochromatosis (NH) is a severe disease of perinatal onset, in which iron deposition occurs within hepatic and extrahepatic sites without involving the reticuloendothelial system. Neonatal haemochromatosis is an iron storage disorder that is among the most common indications for liver transplantation in neonates. Distinct from hereditary haemochromatosis, neonatal haemochromatosis may not be due to a single aetiology, but may be a common endpoint for several infectious, autoimmune, and/or genetic aetiologies. Infants with neonatal haemochromatosis typically present with abdominal distention, jaundice, and hepatomegaly. Typically, decreased albumin, elevated bilirubin, and normal alanine aminotransferase and aspartate aminotransferase values are present. Serum iron levels are often normal, and other markers of iron metabolism, such as elevated ferritin, are nonspecific. Labial salivary gland biopsy has been suggested as a diagnostic adjunct in patients suspected of having $\mathrm{NH}$, because hemosiderin accumulates in acinar epithelial cells. Histology from a minor salivary gland biopsy demonstrates multiple intracellular iron deposits. Similar iron deposits are visible in multinucleated hepatocyte and in Kupffer cells of the liver biopsy. Prior to this salivary gland pathology, diagnosis of NH was often delayed, rendered only after the usual causes of neonatal liver failure had been excluded. Recent studies have shown that early diagnosis and treatment can improve survival [34-36]. Histopathological imaging of labial salivary glands reflects the same symptoms from other organs.

\section{Conclusions}

Labial salivary gland biopsy is advocated in the diagnosis of Sjögren's syndrome. It is a reliable and valuable test with high sensitivity and specificity. The limitation of this biopsy arises from the lack of standardisation of surgical technique. This examination is especially useful in the initial stage of SS and in nonspecific manifestations of SS. LSGB is not a good diagnostic tool for the assessment of SS progression and treatment effectiveness. It seems that parotid gland biopsy is a more valuable test for detecting lymphomas accompanying SS than LSGB. In the other diseases presented, LSGB is rarely applied, but it is worth recommendation. In amyloidosis and neonatal haemochromatosis LSGB may be an important and helpful diagnostic method. In sarcoidosis, the specificity and sensitivity of LSGB seems to be too low, but it may be very useful for distinguishing sarcoidosis from other granulomatous diseases. 


\section{Conflict of interest}

The authors declare no conflict of interest.

\section{References}

1. Andreadis D, Bakopoulou A, Leyhausen G, Epivatianos A, Volk J, Markopoulos A, Geurtsen W. Minor salivary glands of the lips: a novel, easily accessible source of potential/ progenitor cells. Clin Oral Invest 2014; 18: 847-856.

2. Zhao L, Nocturne G, Haskett S, Boudaoud S, Lazure T, La Pajolec C, Mariette X, Mingueneau M, Banerjee X. Clinical relevance of RORgamma positive and negative subsets of CD161+CD4+T cells in primary Sjögren's syndrome. Rheumatology 2017; 56: 303-312.

3. Delli K, Vissink A, Spijkervet FKL. Salivary gland biopsy for Sjögren's syndrome. Oral Maxillofac Surg Clin North Am 2014; 26: 23-33.

4. Kim J, Sun D, Ozl R, Graderbeck T, Birnbaum J, Akpek EK, Baer AN. A validated method of labial minor salivary gland biopsy for the diagnosis of Sjögren's syndrome. Laryngoscope 2016; 126: 2041-2046.

5. Mavragani CP, Moutsopoulos HM. Sjögren's syndrome. Annu Rev Pathol Mech Dis 2014; 9: 273-285.

6. Fox RI. Sjögren's syndrome. Lancet 2005; 366: 321-331.

7. Guellec D, Cornec D, Jousse-Joulin S, Marhadour T, Marcorelles P, Pers JO, Saraux A, Devauchelle-Pensec V. Diagnostic value of labial minor salivary gland biopsy for Sjögren's syndrome: a systematic review. Autoimmun Rev 2013; 12: 416-420.

8. Błochowiak KJ, Trzybulska D, Olewicz-Gawlik A, Sikora J, Nowak-Gabryel M, Kocięcki J, Witmanowski H, Sokalski J. Levels of EGF and VEGF in patients with primary and secondary Sjögrn's syndrome. Adv Clin Exp Med 2018; 4: 455-461.

9. Błochowiak KJ, Olewicz-Gawlik A, Trzybulska D, NowakGabryel M, Kocięcki J, Witmanowski H, Sokalski J. Serum ICAM-1, VCAM-1 and E-selectin levels in patients with primary and secondary Sjögren's syndrome. Adv Clin Exp Med 2017; 26: 835-842.

10. Błochowiak K, Olewicz-Gawlik A, Polańska A, NowakGabryel M, Kocięcki J, Witmanowski H, Sokalski J. Oral mucosal manifestations in primary and secondary Sjögren syndrome and dry mouth syndrome. Adv Dermatol Allergol 2016; 33: 23-27.

11. Olewicz-Gawlik A, Polańska A, Trzybulska D, NowakGabryel M, Błochowiak K, Kocięcki J, Sokalski J, Żaba R, Adamski Z, Dańczak-Pazdrowska A. Skin barrier function in patients with primary and secondary Sjögren's syndrome. Acta Dermatovenerol Croat 2018; 26: 153-156.

12. Shiboski CH, Shiboski SC, le Seror R, Criswell LA, Labetoulle M, Lietman TM, Rasmussen A, Scofield H, Vitali C, Bowman SJ, Mariette X, and the International Sjögren's Syndrome Criteria Working Group2016. American College of Rheumatology/European League Against Rheumatism Classification Criteria for Primary Sjögren's Syndrome. A Consensus and Data-Driven Methodology Involving Three International Patient Cohorts. Ann Rheum Dis 2017; 76: 9-16.

13. Shiboski CH, Shiboski SC, Seror R. 2016 America College of Rheumatology/European League Against Rheumatism Classification Criteria for primary Sjögren's syndrome. Arthritis Rheumatol 2017; 69: 35-45.
14. Pereira DL, Vilela VS, Dos Santos TC, Pires FR. Clinical and laboratorial profile and histological features on minor salivary glands from patients under investigation for Sjögren's syndrome. Med Oral Patol Oral Cir Bucal 2014; 19: e237-e241.

15. Kroese F, Haacke E, Bombardieri M. The role of salivary gland histopathology in primary Sjögren's syndrome: promises and pitfalls. Clin Exp Rheumatol 2018; 36 Suppl 112: 222-233.

16. Daniels TE, Cox D, Shiboski CH, Schiødt M, Wu A, Lanfranchi $H$, Umehara H, Zhao Y, Challacombe S, Lam MY, DeSouza Y, Schiødt J, Holm H, Bisio PAM, Gandolfo MS, Sawaki T, Li M, Zhang W, Varghese-Jacob B, Ibsen P, Keszler A, Kurose N, Nojima T, Odell E, Criswell LA, Jordan R, Greenspan JS and For the Sjögren's International Collaborative Clinical Alliance (SICCA) Research Groups. Associations between salivary gland histopathologic diagnoses and phenotypic features of Sjögren's Syndrome (SS) among 1726 registry participants. Arthritis Rheum 2011; 63: 2021-2030.

17. Varela-Centelles P, Sanchez-Sanchez M, Seoane J. Lip biopsy for the diagnosis of Sjögren's syndrome: beware of the punch. Int J Oral Maxillofac Surg 2014; 43: 127-130.

18. Yokogawa N, Lieberman SM, Alawi F, Bout-Tabaku S, Guttenberg M, Sherry DD, Vivino FB. Comparison of labial minor salivary gland biopsies from childhood Sjögren syndrome and age-matched controls. J Rheumatol 2014; 41: 1178-1182.

19. Sarioğlu S, Küçük Ǔ, Cetin P, Sari I, Bŭrlǐk AM. Minor salivary gland evaluation: Sjögren's syndrome. Turk J Med Sci 2016; 46: 63-65.

20. Keszler A, Adler LI, Gandolfo MS, Masquijo Bisio PA, Smith AC, Vollenweider CF, Heidenreich AM, de Stefano G, Kambo MV, Cox DP, Narbaitz M, Lanfranchi HE. MALT lymphoma in labial salivary gland biopsy from Sjögren syndrome: importance of follow-up in early detection. Oral Surg Oral Med Oral Pathol Oral Radiol 2013; 115: e28-33.

21. Haacke E, Bootsma H, Spijkervet FKL, Visser A, Vissink A, Kluin PM, Kroese FGM. FcRL4+ B-cells in salivary glands of primary Sjögren's syndrome patients. J Autoimm 2017; 81: 90-98.

22. Theander E, Vasaitis L, Baecklund E, Nordmark G, Warfvinge $\mathrm{G}$, Liedholm R, Brokstad K, Jonsson R, Jonsson MV. Lymphoid organisation in labial salivary gland biopsies is a possible predictor for the development of malignant lymphoma in primary Sjögren's syndrome. Ann Rheum Dis 2011; 70: 1363-1368.

23. Bende RJ, Slot LM, Hoogeboom R, Wormhoudt TA, Adeoye AO, Guikema JE, van Noesel CJ. Stereotypic rheumatoid factors that are frequently expressed in mucosa-associated lymphoid tissue-type lymphomas are rare in the labial salivary glands of patients with Sjögren's syndrome. Arthritis Rheumatol 2015; 67: 1074-1083.

24. Baer AN, Gourin CG, Westra WH, Cox DP, Greenspan JS, Daniels TE; Sjögren's International Collaborative Alliance. Rare diagnosis of IgG4-related systemic disease by lip biopsy in an international Sjögren syndrome registry. Oral Surg Oral Med Oral Pathol Oral Radiol 2013; 115: e34-e39.

25. Sacsaquispe SJ, Antúnez-de Mayolo EA, Vicetti R, Delgado WA. Detection of AA-type amyloid protein in labial 
salivary glands. Med Oral Patol Oral Cir Bucal 2011; 16: e149-e152.

26. Hachulla E, Janin A, Flipo RM, Saïle R, Facon T, Bataille D, Vanhille P, Hatron PY, Devulder B, Duquesnoy B. Labial salivary gland biopsy is a reliable test for the diagnosis of primary and secondary amyloidosis. A prospective clinical and immunohistologic study in 59 patients. Arthritis Rheum 1993; 36: 691-697.

27. Suzuki T, Kusumoto S, Yamashita T, Masuda A, Kinoshita S, Yoshida T, Takami-Mori F, Takino H, Ito A, Ri M, Ishida T, Komatsu H, Ueda M, Ando Y, Inagaki H, Iida S. Labial salivary gland biopsy for diagnosing immunoglobulin light chain amyloidosis: a retrospective analysis. Ann Hematol 2016; 95: 279-285.

28. Amaral B, Coelho T, Sousa A, Guimarães A. Usefulness of labial salivary gland biopsy in familial amyloid polyneuropathy Portuguese type. Amyloid 2009; 16: 232-238.

29. Hachulla E, Grateau G. Diagnostic tools for amyloidosis. Joint Bone Spine 2002; 69: 538-545.

30. Alawi F. An update on granulomatous diseases of the oral tissues. Dent Clin North Am 2013; 57: 657-671.

31. Valeyre D, Bernaudin JF, Uzunhan Y, Kambouchner M, Brillet PY, Soussan M, Nunes H. Clinical presentation of sarcoidosis and diagnostic work-up. Semin Respir Crit Care Med 2014; 35: 336-351.

32. Wessendorf TE, Bonella F, Costabel U. Diagnosis of sarcoidosis. Clin Rev Allergy Immunol 2015; 49: 54-62.

33. Bernard C, Kodjikian L, Bancel B, Isaac S, Broussolle C, Seve P. Ocular sarcoidosis: when should labial salivary gland biopsy be performed? Graefes Arch Clin Exp Ophthalmol 2013; 251: 855-860.

34. Chan KC, Edelman M, Fantasia JE. Labial salivary gland involvement in neonatal hemochromatosis: a report of 2 cases and review of literature. Oral Surg Oral Med Oral Pathol Oral Radiol Endod 2008; 106: e27-e30.

35. Smith SR, Shneider BL, Magid M, Martin G, Rothschild M. Minor salivary gland biopsy in neonatal hemochromatosis. Arch Otolaryngol Head Neck Surg 2004; 130: 760-763.

36. Udell IW, Barshes NR, Voloyiannis T, Lee TC, Karpen SJ Carter BA, Finegold M, Goss JA. Neonatal hemochromatosis: radiographical and histological signs. Liver Transpl 2005; 11: 998-1000.

\section{Address for correspondence:}

Bartłomiej Kamiński MD, PhD

Otolaryngology Ward

Maria Sklodowska-Curie District Hospital

ul. Szpitalna S1, 26-110 Skarżysko-Kamienna, Poland

Phone: +48602 491654

E-mail: bartl.kaminski@gmail.com 